\title{
The impact of national institutional context on social practices: comparing Finnish and US business communities
}

\author{
Jill M. Purdy* and Elizabeth A. Alexander \\ Milgard School of Business, \\ University of Washington, \\ Tacoma, 1900 Commerce Street, \\ Box 358420, Tacoma, WA 98402, USA
}

\section{Stern Neill}

Orfalea College of Business,

California Polytechnic State University,

1 Grand Avenue, San Luis Obispo,

CA 93407, USA

\begin{abstract}
This paper investigates the impact of national institutional contexts on firms' socially responsible practices, the motives for such practices and methods of organising social practices. Surveys of firms in a liberal market economy (USA) and those in a coordinated market economy (Finland) are compared. Findings indicate that social practices differ between the contexts, providing empirical support for the theory of explicit and implicit forms of corporate social responsibility. The paper offers insight into how social practices are organised in different contexts and a new conceptualisation of the motives for social responsibility. Results suggest that national institutional context should be accounted for in empirical studies of business social practices.
\end{abstract}

Keywords: social responsibility; CSR; corporate social responsibility; social practices; national context; liberal market economy; coordinated market economy; institutional theory; Finland; USA; institutional context; implicit CSR; explicit CSR.

Reference to this paper should be made as follows: Purdy, J.M. and Alexander, E.A. and Neill, S. (2010) 'The impact of national institutional context on social practices: comparing Finnish and US business communities', European J. International Management, Vol. 4, No. 3, pp.234-256.

Biographical notes: Jill M. Purdy (PhD Pennsylvania State University) is an Associate Professor and the Academic Director of the Center for Leadership and Social Responsibility at the Milgard School of Business. She has taught at universities in the USA, Iceland and Finland. Her current scholarship focuses on institutional influences on social responsibility and business practices. Her research has been published in Academy of Management Journal, Academy 
of Management Learning and Education, International Journal of Conflict Management and Public Administration Quarterly. She also serves on the editorial boards of Negotiation and Conflict Management Research and Bifröst Journal of Social Science.

Elizabeth A. Alexander is an Assistant Professor in the Milgard School of Business. She holds an MBA from the University of Strathclyde and a BA from the University of Oxford. She earned her Doctorate in Strategic Management and Public Policy with an interdisciplinary minor in political economy and international business from the School of Business at the George Washington University, Washington DC, in 2007. Her current research focuses primarily on the relationship between national institutional environments and business strategy, performance and organisation. She has private sector experience of working with both SMEs and public sector agents in economic development in the UK.

Stern Neill is an Associate Professor at the Orfalea College of Business at California Polytechnic State University. His scholarly interests are in the areas of marketing strategy, decision-making and firm performance. He received his $\mathrm{PhD}$ in Business Administration from Louisiana State University in 2000. His research appears in the Journal of Business Research, Industrial Marketing Management and others.

\section{Introduction}

Multiple theoretical models of Corporate Social Responsibility (CSR) have emerged to explain how and why companies engage in creating social benefits, including ethicsbased approaches (Carroll, 1979), stakeholder-based approaches (Freeman, 1984), strategic approaches (Kotler and Lee, 2005; Porter and Kramer, 2006) and economic approaches (Orlitzky et al., 2003). A weakness of these approaches for international scholars is their limited attention to the effects of national context. Recently, institutional theorists have begun investigating how context affects CSR, considering both national business systems (Matten and Moon, 2008) and the role of local communities (Marquis et al., 2007) in influencing how businesses interpret and attend to their obligations to society. At the national level, factors such as economic structure, the role of the nationstate and the socio-cultural orientation of a country create fundamentally different contexts in which businesses interpret their responsibilities towards society and consider actions to fulfil those obligations. This institutional context at the national level generates unwritten rules about appropriate practices for organisations that are followed because to violate them would make the organisation illegitimate (Meyer and Rowan, 1977), resulting in different perceptions, language, intentions and practices related to CSR internationally.

The recognition that national institutional frameworks for CSR vary across nationstates (Habisch et al., 2005) has resulted in new conceptualisations of CSR that are more sensitive to international differences. For example, Matten and Moon (2008) have described two forms of CSR resulting from differing institutional contexts in the USA and Europe. The explicit approach to CSR, typical in the USA, results from the belief that individual organisations are responsible for societal interests. The implicit approach to CSR, more typical of European firms, reflects organisations' roles within wider 
institutions that address societal interests. This new theoretical approach generates a need for empirical research to investigate the effects of national institutional context on how social responsibility is interpreted and acted upon.

Empirical research considering the effect of national institutional environments on CSR practices is emerging (Chapple and Moon, 2005; Williams and Aguilera, 2008). Several descriptive studies have examined relationships between stages of economic and institutional development and the adoption of CSR practices (Welford, 2005; Baughn et al., 2007), linking within country contexts to differences in CSR modes across Asian countries (Chapple and Moon, 2005) and analysing how firms in the USA, UK, France and the Netherlands self-publicise their CSR processes (Maignan and Ralston, 2002). While a few studies provide cross-country comparative studies of firms' approaches to CSR (Brammer and Pavelin, 2005; Chapple and Moon, 2005), additional research, particularly on Small and Medium-sized Enterprises (SMEs), is needed to provide a more nuanced examination of 'practice, context, and implications' (Spence, 2007, p.542).

To provide insight into how institutional context may influence firms' CSR motives and practices, we offer an empirical study that compares firms in an explicit CSR context (USA) with those in an implicit CSR context (Finland). Our examination includes SMEs and attends to the social practices of businesses by considering the form, focus and level of activities in which they engage. We also consider whether the two contexts differ in the motives that companies offer for engaging in social practices and in the degree to which companies have formalised organisational mechanisms to manage their CSR activities. By investigating firms' practices, motives and organisation around social responsibility in different contexts, we reveal the impact that national institutional context has on how firms interpret and enact social responsibility. Our findings have implications for how CSR is understood and evaluated in the global economy.

\section{Theoretical background}

\subsection{National institutional context}

We draw on two complementary approaches to explain national institutional arrangements (see Table 1). Jepperson's (2002) model focuses on societal arrangements, differentiating between corporate and associational bases of organising society and the degree to which governance is embodied in a collective decision-making system. Collective decisionmaking is represented by authority centralised either in the state or in civil society, explaining differences between advanced economies (Nettl, 1968). Jepperson (2002) argued that Germany and Japan are strong states dominated by corporate interests, while France has a strong state but is organised around a hierarchical structure of associations. In contrast to these strong statist governance arrangements, Jepperson (2002) identified the UK, the USA and the Nordic countries as 'societal,' akin to Nettl's (1968) concept of low 'stateness'. In Jepperson's 'societal' countries, authority is conferred by, and decision-making emerges from, a process of interaction between interest groups and publics, whether in a more corporatist mode in which the state performs a coordinating function (the Nordic states or 'social-corporate' model) or in an associational mode of liberal pluralism (the USA and UK). 
Table 1 National institutional context classifications

\begin{tabular}{|c|c|c|c|c|}
\hline \multirow{2}{*}{$\begin{array}{l}\text { Jepperson (2002) } \\
\text { Polity form } \\
\text { classification }\end{array}$} & \multirow[b]{2}{*}{ Countries } & \multicolumn{3}{|c|}{$\begin{array}{l}\text { Varieties of Capitalism-Coordination index } \\
\text { Hall and Gingerich }(2004, \text { p. 14) }\end{array}$} \\
\hline & & $\begin{array}{l}\text { Coordination } \\
\text { index }\end{array}$ & Countries & Classification \\
\hline \multirow[t]{3}{*}{ Liberal } & USA & 0.00 & USA & \multirow{16}{*}{$\begin{array}{l}\text { Liberal market } \\
\text { economies } \\
\text { (coordination } \\
\text { through competitive } \\
\text { markets) }\end{array}$} \\
\hline & UK & 0.07 & UK & \\
\hline & Australia & 0.13 & Canada & \\
\hline \multirow[t]{4}{*}{ Social Corporatist } & Norway & 0.21 & New Zealand & \\
\hline & Sweden & 0.29 & Ireland & \\
\hline & Denmark & 0.36 & Australia & \\
\hline & Finland & 0.51 & Switzerland & \\
\hline \multirow[t]{3}{*}{ State-Nation } & France & 0.57 & Spain & \\
\hline & Italy* & 0.66 & Netherlands & \\
\hline & Belgium* & 0.69 & Sweden & \\
\hline \multirow[t]{10}{*}{ State-Corporate } & Germany & 0.69 & France & \\
\hline & Japan & 0.70 & Denmark & \\
\hline & & 0.72 & Finland & \\
\hline & & 0.72 & Portugal & \\
\hline & & 0.74 & Japan & \\
\hline & & 0.74 & Belgium & \\
\hline & & 0.76 & Norway & \multirow{4}{*}{$\begin{array}{l}\text { Coordinated market } \\
\text { economies } \\
\text { (coordination } \\
\text { through strategic } \\
\text { interaction) }\end{array}$} \\
\hline & & 0.87 & Italy & \\
\hline & & 0.95 & Germany & \\
\hline & & 1.00 & Austria & \\
\hline
\end{tabular}

Note: *Spencer et al. (2005).

A second approach, Varieties of Capitalism (VOC), builds on the idea of strong or weak states and pluralist or corporatist states to characterise institutional differences in national political economies, especially in light of increased global interdependence (Crouch and Streeck, 1997; Hollingsworth and Boyer, 1997; Kitschelt et al., 1999; Whitley, 1999; Hall and Soskice, 2001; Hall and Gingerich, 2004). The VOC approach suggests that the issue of coordination is not a trade-off between groups in terms of power-based relations (Schmitter, 1974; Katzenstein, 1985), but rather social relations underpinned by common interests in maintaining the production system, which itself is embedded in the broader state-societal and associational-corporatist logics developed in Jepperson's (2002) framework. Hall and Soskice (2001) examine how firms interact with critical institutions to solve coordination problems in a firm-centred political economy, recognising formal and informal institutional arrangements that differ across countries. Focusing on OECD countries, Hall and Gingerich (2004) place national institutional arrangements along a continuum from liberal market economies to coordinated market economies. At the one end of the spectrum, coordination by economic actors occurs through market institutions and formal contracting in liberal market economies. Such economies include the USA and the UK, and this liberal market category is similar to Jepperson's (2002) associational 
pluralism form (see Table 1). At the other end of the spectrum, non-market relationships provide the key to solve coordination problems. Countries in this category of "coordinated market economies' include Germany and Austria as the anchors, but Finland ranks high on the coordination index along with other European countries, such as Denmark, Belgium and Norway (Hall and Gingerich, 2004). In contrast to liberal market economies, non-market relationships in coordinated economies include strong business networks, employer associations and unions, as well as cross-shareholdings (Hall and Soskice, 2001).

These institutional systems influence business social practices through differences in how states address social welfare, labour polices, corporate governance and businessgovernment relationships. First, expectations about the role of the firm versus the state are derived from approaches to social welfare. In coordinated contexts, social welfare policy is based on a sense of universalism and a rejection of market forces, such as in the Nordic countries (Esping-Andersen, 1999). Countries with strong liberal market traditions instead emphasise market-based solutions to many elements of social welfare, often centred on the firm as the coordinator or provider. Second, the legal frameworks governing labour in coordinated markets, such as co-determination in Germany, ensure that firms are engaged in a continuous dialogue with labour around many central tenets of CSR. Such dialogue is limited or absent in liberal market economies. Third, in contrast to 'shareholder' models of corporate governance that typify liberal market economies, coordinated economies exhibit greater cross-shareholding between companies, financial institutions and investors based on cooperative institutional arrangements (Thomas and Waring, 1999). Such integrative governance models support discourse about social policies as a central element of regular business decisions, while in liberal market-based economies, market forces and regulations inhibit this level of dialogue, creating a need for firms to communicate CSR actions more publically. Finally, the US business system is characterised by autonomy in business-government relationships and typically adversarial relations between government and firms with regard to regulation (Vogel, 1996). Policymaking in liberal market economies is a contested political and legal process, whereas the policy process in coordinated market economies provides firms, an incentive for coordinated action through organised producer groups (Scruggs, 1999). Institutional arrangements emphasising collective action between the state, civil society and firms help explain why European firms are more accepting of government involvement in CSR than firms in the USA (Aaronson and Reeves, 2002).

\subsection{Implicit and explicit CSR}

Matten and Moon's (2008) research proposes explicit and implicit forms of CSR to describe how organisations in different contexts both interpret and enact their social obligations. Explicit CSR results in corporate policies that "assume and articulate responsibility for some societal interests" (Matten and Moon 2008, p.409). These responsibilities are carried out in the form of voluntary activities that link business and social value, and are focused on areas perceived as part of a company's social responsibility. Explicit CSR represents the deliberate, voluntary and often strategic (Porter and Kramer, 2006) decisions of a company. In contrast, implicit CSR refers to "corporations' role within the wider formal and informal institutions for society's interests and concerns" (Matten and Moon 2008, p.409). Implicit CSR consists of values, norms and rules that frame how companies address stakeholder issues, and it reflects a 
collective rather than individual interpretation of corporate obligations towards society. Implicit CSR is not conceived of as a voluntary and deliberate corporate decision, but rather as a reflection of a company's institutional environment. Underlying societal norms, networks, organisations and rules guide the social practices of businesses, but are constituted at a collective level such that firms are less likely to claim ownership for them and may not consider them as 'CSR'. The distinction between implicit and explicit forms of CSR is important in a descriptive sense for understanding what constitutes CSR in different global contexts. Without such a distinction, research using the explicit CSR framework may fail to adequately capture the full range of socially responsible actions in implicit CSR contexts.

Differences between European implicit approaches and the US explicit approaches to CSR are logical outcome of differences in state-society relations. European governments, for example, provide greater support for social welfare, education and cultural activities that is a key focus of corporate philanthropy in the USA. Further, European governments act as coordinators of CSR policy and may actively promote CSR, while the explicit CSR of the US business community has emerged without coordination by the state, driven by a long-standing philanthropic tradition and in response to critique of US multinationals' activities overseas (Bertelsmann Stiftung Institute, 2007).

The definition of what constitutes CSR is linked to implicit and explicit conceptions of CSR. For example, a commonly used definition of CSR refers to "the firm's consideration of, and response to, issues beyond the narrow economic, technical, and legal [and environmental] requirements of the firm" (Davis, 1973, p.312), representing acceptance of a social obligation and voluntary action beyond mere compliance with the law. A key element of this voluntary action relates to the engagement of the firm in social practices that go beyond the boundaries of the firm, including philanthropy or corporate giving (Carroll, 1991; Saiia et al., 2003). Evidence suggests that small firms in many nations consider philanthropic giving as an element of CSR (Vives, 2006; Jamali et al., 2009; Russo and Tencati, 2009). However, the EU approach to CSR focuses strongly on management practices internal to the firm, with "companies integrating social and environmental concerns in their daily business operations and in their interaction with their stakeholders on a voluntary basis" (European Commission, 2001). To capture the full range of socially responsible practices as understood by organisations in differing institutional contexts, our research considers both the social practices that occur external to the firm and the underlying motives and actions within the firm that give rise to these practices, allowing us to empirically study both implicit and explicit forms of CSR.

\subsection{National institutional contexts of the USA and Finland}

To better understand the impact on national institutional context on CSR, we studied a cross-section of firms in two countries. The USA and Finland were selected for this study as representative of the liberal and coordinated market economies, respectively. The USA and Finland differ in the degree of state centredness and in the degree of coordination through collective strategies versus more individualistic approaches. The greater state centredness of Finland is indicated by its larger aggregate tax rate of $43.5 \%$ compared with $28.2 \%$ of the USA (OECD, 2008), as well as the presence of nationally coordinated CSR efforts such as the governmental Committee on International Investment and Multinational Enterprise (MONIKA), which guides CSR action and the Corporate Responsibility Finland programme (European Commission, 2007). In contrast, the US 
federal government does not coordinate CSR policy and does not actively promote a CSR agenda. CSR efforts are spread across 12 federal agencies and 50 programmes (GAO, 2005), and myriad approaches have emerged from the private sector (Bertelsmann Stiftung Institute, 2007). The stronger collective orientation in Finland is signalled by a measure of economic equality, the Gini coefficient, where zero represents perfect equality among citizens. The Gini coefficient for the USA is 46.6 (US Census Bureau, 2009 ) compared with 26 for Finland (Eurofound, 2006). Further, Finland's individualismcollectivism score in Hofstede's (2001) seminal research (63) indicates a society where people are integrated into strong, cohesive social groups, while the US score (91) was the highest among all nations, indicating a society where individual responsibility dominates.

\section{Hypotheses}

To understand the impact of national institutional context on firm-level CSR, this research compares Finnish and US firms' social practices, motives for CSR and formalised organisation around CSR. Social practices are defined as the actions that businesses take to discharge their responsibilities towards society, on the dimensions of form, focus and level (Marquis et al., 2007). Motives for CSR indicate how businesses in a specific context interpret their social responsibility and the factors they perceive as influencing their actions. Formalised organisation around CSR describes the internal methods that firms use to select and manage their CSR activities. Our model of the relationship between national institutional context and CSR is shown in Figure 1. We predict national institutional context will have both direct and mediated effects on a firm's social practices. We propose a direct influence on the motives of firms for engaging in CSR, the degree of formalisation around CSR and the form, focus and level of the firm's corporate social practice. Our model also suggests that the motives and degree of formalisation of approaches to CSR will be reflected in the form, focus and level of social practices, although those relationships (indicated by dotted lines) are not tested here. Our study includes a cross-section of firms to ensure that both larger corporations and SMEs are included, as firms of all sizes should be impacted by national institutional context.

Figure 1 The effect of national institutional context on CSR

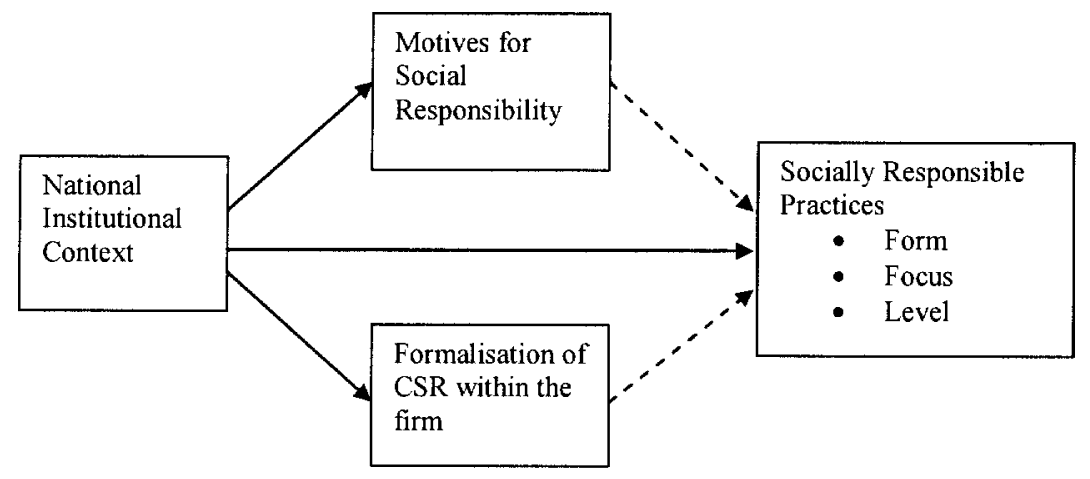




\subsection{Form of social practices}

Form describes the ways in which businesses engage in meeting the needs of society, such as through community involvement, cash donations or volunteering (Guthrie, 2003). We offer hypotheses regarding two forms of giving associated with explicit CSR: cash donations and employee volunteering. In liberal market economies, cash donations are a tangible, visible means of providing support to social needs while retaining individual choice and allowing market dynamics to operate within the non-profit sector. US firms have a long tradition of cash donations to charitable organisations (Useem, 1988). In coordinated market economies, cash resources are more likely to be funnelled through state- or association-coordinated mechanisms that redistribute funds to support social needs. In coordinated contexts, cash contributions may not be labelled or accounted for as CSR related, thus we expect a higher frequency of firms in the liberal market context to report giving in the form of cash contributions.

Hypothesis Ia: Firms in liberal market economies are more likely to contribute through cash donations than firms in coordinated market economies.

Volunteering as a form of CSR is another tangible, highly visible means of giving. Employee involvement in community-based activities is typically low among European SMEs (The Observatory of European SMEs, 2002), whereas company coordination of and support for employee volunteering is commonplace in the USA even among small businesses (Thompson et al., 1993). Research on employee volunteering as a form of CSR, conducted primarily in liberal market economies, emphasises the human resource benefits to companies more than community and societal benefits (Lee and Higgins, 2001). This suggests firms in liberal market economies frame volunteering in terms of employee commitment and skill development, reflecting an individualistic perspective. In coordinated market economies, structures for coordinating voluntary activity are more likely to be offered by the state or by societal groups other than business firms. Thus, we expect firms in liberal market economies to have a higher frequency of employee volunteering than those in coordinated market economies.

Hypothesis Ib: Firms in liberal market economies are more likely to contribute through employee volunteering than firms in coordinated market economies.

\subsection{Focus of social practices}

Focus describes the issues or purposes to which businesses give, such as arts, education, social welfare or the environment (Useem, 1991; Marquis et al., 2007). Coordinated market economies support arts, education and social services collectively; the level of state spending represents an underlying societal commitment to, and expectation of, government rather than corporate involvement in meeting society's needs. In Finland, public expenditure on social services accounts for $22.5 \%$ of GDP compared with $16.2 \%$ in the USA, while spending on education by the Finnish government accounts for $6 \%$ of GDP compared with $5.1 \%$ in the USA (OECD, 2008). In liberal market economies, the need for and expectation of private support of health, human services and education has led to these becoming the primary areas in which US businesses make charitable contributions (Useem, 1988). Individual businesses may focus their activities to align with customers' interests or to ensure a future supply of qualified human resources (Useem, 1991). 
Hypothesis 2a: Firms in liberal market economies are more likely to support the arts, education and social needs through social practices than firms in coordinated market economies.

In liberal market economies, the government's role in managing environmental issues is largely regulatory and individual firms retain choice over the nature and extent of environmental activities. In coordinated market economies, the cooperative nature of business-government relations and the more collectivist orientation create coordinated policies and shared expectations about the environmental actions of businesses, removing environmental concerns from the domain of individual company CSR. Data from our subject countries support this conceptualisation. For example, Finns generally prioritise environmental protection above economic growth: $82 \%$ of Finns are against economic growth if it means the environment is affected (Eurobarometer, 2008). Efforts to manage environmental outcomes in Finland have been spurred by the capital and energy intensity of the paper and pulp industry (Korhonen and Seppala, 2005) leading to coordinated action at the national rather than business level. In contrast, US citizens hold a more laissez-faire attitude towards environmental protection by government; $43 \%$ of the USA felt that the government should not attach a priority to promoting environmental action to reduce pollution, compared with $34 \%$ of Finns (World Values Survey, 2000).

Hypothesis 2b: Firms in liberal market economies are more likely to support the environment through social practices than firms in coordinated market economies.

\subsection{Level of social practices}

Level describes the quantity or size of CSR effort relative to the organisation's resource capacity. Given the difficulty of measuring CSR efforts, our hypothesis focuses on the amount of funds that organisations contribute for all types of issues. Matten and Moon's theory suggests that voluntary cash donation is an explicit form of CSR and thus will be more strongly associated with the liberal market economy. In coordinated market economies, funds that support social issues may be accounted for as taxes rather than labelled as CSR related, while normative pressures may influence cash donations in the liberal market context. Norms for charitable giving have long been established in the USA, with large firms typically donating between $1 \%$ and $2 \%$ of their pre-tax profits to charity (Seifert et al., 2004) and small businesses on average donating $0.2 \%$ of revenues to charity (Thompson et al., 1993). Because these norms are widely known, they serve as informal standards for firms in the USA.

Hypothesis 3: Firms in market economies will demonstrate a higher level of giving of funds than firms in coordinated market economies.

\subsection{Motives for social practices}

Matten and Moon (2008) assert that societal norms are more explicit in collective societies and thus CSR is based on the taken-for-granted notion that businesses follow the established rules in society. In a coordinated market economy where multiple institutions have interpenetrating interests, institutional expectations may be unambiguous and more influential on a firm's CSR practices. Firms embedded in thick layers of interpenetrating relationships tend to develop a broader societal motivation for stakeholder 
engagement based on a sense of common purpose (Brickson, 2007). In contrast, firms in liberal market economies, where market transactions dominate relationships, may focus more on the need for buy-in from a smaller set of stakeholders. The lack of coordination in liberal market economies results in institutional voids with a variety of unfulfilled social needs. Under conditions of institutional ambiguity, firms have greater discretion over their practices (Goodrick and Salancik, 1996), thus companies can leverage their resources for economic or reputational reasons, as well to achieve legitimacy.

Hypothesis 4a: Firms in liberal market economies are more likely to give for economic and reputational reasons than firms in coordinated market economies.

Hypothesis $4 b$ : Firms in coordinated market economies are more likely to give for social conformity and values reasons than firms in liberal market economies.

\subsection{Formalisation of CSR within the organisation}

In addition to influencing practices and motives, national institutional context is likely to influence firms' internal mechanisms for handling CSR processes (de Graaf and Herkströter, 2007). Both the state centredness and the collectivism in coordinated market economies support lower usage of CSR organising methods within firms. Functions, such as environmental scanning, needs assessment and issue management, are likely to be supported at the collective level, either by the state or by non-state organisations that are created for this purpose. Thus formalising CSR information gathering and decisionmaking functions within the firm are unnecessary within the organisation. One study supports the notion that Finnish firms take an unsystematic approach to CSR (Panapanaan et al., 2003), while structures such as MONIKA in Finland provide coordination outside the individual firm. In liberal market economies, the market-based approach extends to the recognition and fulfilment of social needs, and coordinating mechanisms for environmental scanning and need fulfilment are more limited. Firms that wish to engage in CSR thus must create internal structures and mechanisms for environmental scanning and issue management and do so because of the perceived benefit to the individual firm. The CSR efforts of USA firms have become increasingly organised within corporations (Useem, 1988).

Hypothesis 5: Firms in coordinated market economies will report lower levels of CSR organisation than firms in liberal market economies.

\section{Methods}

Our study compares the social practices, motives and organising methods of firms in liberal and coordinated market economies. We include firms of all sizes in recognition of growing attention to the social practices of SMEs (cf. Mack, 1999; Perrini et al., 2007) which constitute the majority of businesses. We adopted an inductive approach rather than deriving our definitions and measures from corporate reporting initiatives geared towards large firms (Vuontisjärvi, 2006) or participation in global CSR indices (Gjølberg, 2009), as such reporting systems have been deemed inappropriate for SMEs (Fassin, 2008). In each country, we conducted semi-structured interviews with high-level managers at eight different firms. Transcripts of the interviews were analysed to compile 
a list of external and internal social practices identified by interviewees. This allowed us to capture our subjects' understanding of CSR and social practices in both national institutional contexts. We then created single and multi-item measures to reflect existing theoretical models and the insights of our interview subjects.

To assess the measures and test the hypotheses, data were gathered via internet-based surveys from business executives involved in CSR activities at their firms. Unidimensionality of multi-item scales was assessed by using item-to-scale correlations, exploratory factor analysis and Cronbach's alpha. Appendix A lists the scale reliabilities for the study's measures. A series of analyses were performed to test the effect of national institutional context on socially responsible practices, as well as the motives for and formalisation of such practices.

\subsection{Sample}

Our sample was drawn from firms located either in the South Savo region of Finland or in Pierce County of Washington State in the USA. Region-based data collection was selected (a) to ensure the inclusion of SMEs in the sample and (b) to limit variation due to community, rather than national-level institutional influences (cf. Marquis et al., 2007). The South Savo region of Finland is located in Eastern Finland with a population of approximately 160,000 (Statistics Finland, 2008). Of more than 8200 businesses in the region, over $90 \%$ are small businesses employing fewer than ten persons (Statistics Finland, 2008). Pierce County is located in western Washington in the north-western USA with a population of approximately 790,000 (US Census Bureau, 2008). Of more than 19,000 businesses in the county, $89 \%$ are small businesses employing fewer than 20 persons (US Census Bureau, 2008).

Surveys were conducted in cooperation with each region's Chamber of Commerce, a membership organisation for businesses of all sizes and industries. In South Savo, additional survey responses were solicited from members of the South Savo Entrepreneurs, an organisation for small businesses. We sent survey requests to 1485 companies in Finland and received 116 responses yielding a $7.8 \%$ response rate. In the USA, we solicited responses from 1029 companies and received 109 responses, yielding a $10.6 \%$ response rate. After eliminating surveys where the respondent was not deemed qualified to represent the organisation, the final sample size was 107 for Finland and 106 for the USA. Qualified respondents held managerial positions and were involved in decisionmaking processes related to social responsibility. In the USA, $80 \%$ of respondents were top executives while in Finland $87 \%$ were top executives. The samples are representative of the industries and sizes of businesses in each region.

\subsection{Data collection}

The first section of the survey asked respondents about company giving in the form of funds (cash), non-cash donations, volunteering and sponsorships, which were derived from prior CSR research (Marquis et al., 2007) and our semi-structured interviews. Because theory suggests that CSR practices may be framed differently in different contexts and by different size organisations (Murillo and Lozano, 2006), and our interviews may not have captured the full range of possibilities, we included opportunities for writein responses to capture respondents' interpretations of what social practices are. For example, the survey asked, 'Does your company give in other ways we have not asked 
about?' This section also asked about the degree of support given to arts and culture, education, environment, health and wellness, and social and public need, using a fivepoint Likert scale rated from 'a great deal' to 'none'.

The second section addressed motives for giving, asking 'How important is each of the following factors in guiding your company's social practices?' Respondents rated on a seven-point Likert scale the importance of 21 items representing four categories of motives: economic, reputation, social conformity and values (see Appendix A for items, which were derived from qualitative interviews conducted with eight business owners in each country). This section also asked respondents to rate on a seven-point scale how commonly they used various methods for organising and implementing social responsibility (see Appendix A for items, which were derived from Kotler and Lee, 2005). The third section collected demographic information on the organisation and the survey respondent.

\subsection{Translation process}

We accomplished the translation process using a multiple-stage committee process (Douglas and Craig, 2007) involving nine bilingual Finnish-English speakers: eight native Finns and one native of the USA. Three translators had substantial experience (six months or more) living in both countries. The process involved two teams of three people who independently translated from US English to Finnish, then negotiated a final translation between the teams. A third team of three individuals undertook back translation from the final Finnish version into US English. In addition the final survey in Finnish was independently back translated by a bilingual Finn, who also translated the responses to open-ended survey questions on completed surveys.

When translating to Finnish, we sought to create parallel meanings rather than simply obtaining linguistic equivalence. The process enabled us to check for functional equivalence in the scale items to ensure common understanding and category equivalence. During translation, the teams identified three expressions for which the languages were deemed incommensurate such that equivalent meaning was difficult to achieve. In these cases the translators suggested revised language for both the Finnish and the English surveys to achieve commensurability. These changes were accepted into final versions of both surveys. Using this translation process ensured we did not encounter difficulties in scale equivalence and we could be confidant of similarity in response styles (Diamantopoulos et al., 2006).

\section{Results}

To test the hypotheses, a series of bivariate analyses were performed. Table 2 summarises the results relating to form of socially responsible practices. In support of Hypotheses $1 \mathrm{a}$ and $\mathrm{lb}$, firms in a liberal market economy are more likely to donate funds $\left(\chi^{2}=52.00\right.$ with 1 d.f., $\left.p<0.01\right)$ and contribute volunteer days $\left(\chi^{2}=28.88\right.$ with 1 d.f., $p<.01$ ) than firms in a coordinated market economy. However, when the level of contribution is considered (Table 3), even though firms in the USA are more likely to contribute volunteer days, they have a lower average number of volunteer days per employee (8.56 versus 9.62). Although we offered no hypotheses regarding other forms of social practices, our data indicate that firms in a liberal market economy are more 
likely to make non-cash contributions $\left(\chi^{2}=8.20\right.$ with $\left.1 d f_{.,} p<.01\right)$ and less likely to engage in sponsorships $\left(\chi^{2}=4.39\right.$ with $\left.1 d f ., p<.05\right)$ than firms in a coordinated market economy.

Table 2 Percent of firms participating in forms of social responsibility

\begin{tabular}{lcc}
\hline Form & Liberal market context & Coordinated market context \\
\hline Funds & 89.3 & 32.1 \\
Non-cash donations & 76.9 & 46.8 \\
Volunteering & 80.8 & 37.1 \\
Sponsorships & 69.7 & 49.7 \\
\hline
\end{tabular}

Table 3 reports the results with respect to focus and level of social practices. Firms in a liberal market economy indicate a greater level of support for all focus areas compared with coordinated market economy firms. In partial support of Hypothesis 2a, firms in a liberal market economy more strongly support education ( $t$-value $=9.30, p<.01$ ) and social and public need $(t$-value $13.45, p<.01$ ). While slightly stronger support for the arts was indicated among liberal market economy firms, the difference was not statistically significant. In support of Hypothesis $2 b$, firms in a liberal market economy more strongly support the environment ( $t$-value $=3.69, p<.01$ ) than firms in a coordinated market economy. Write-in responses provide interesting results regarding the focus of giving. $76 \%$ of Finnish respondents $(n=81)$ indicated that they gave to support other kinds of activities not included in the five survey categories of arts and culture, education, environment, health and wellness, and social and public need. Among respondents indicating they gave to other causes, $38 \%$ indicated they supported sports activities (which they viewed as distinct from health and wellness), and this was rated as more than moderately important (mean $=3.6$ where $5=$ a great deal) Other write-in responses included veteran's organisations, membership organisations, such as the Chamber of Commerce, and fraternal organisations, such as the Lions Club. Among USA respondents, $35 \%$ of respondents $(n=37)$ indicated that the focus of their support was outside the survey categories listed. Write-in responses indicated support for various communities, and religious causes, but responses did not converge around an alternate focus area as they did for Finnish firms. Support in the USA was at a lower level for these 'other' areas (mean $=2.19$ ) than for the five categories listed on the survey.

In support of Hypothesis 3 , firms in a liberal market economy donated more funds ( $t$-value $=2.20, p<.05$ ) than firms in a coordinated market economy. While we did not offer predictions about the levels of support related to other forms of giving, our results indicate that Finnish firms contributed significantly more support in the form of sponsorships than their USA counterparts $(t$-value $=2.00, p<.05)$.

Table 4 summarises the results relating to the effect of national institutional context on motives for and formalisation of a firm's socially responsible practices. The results for Hypothesis 4 are mixed. Firms in a liberal market economy report significantly higher importance for each motive: economic $(t$-value $=2.54, p<.01)$, reputation ( $t$-value $=$ $3.72, p<.01)$, social conformity $(t$-value $=2.17, p<.05)$ and values $(t$-value $=5.88$, $p<.01$ ), although we had expected that this would hold true only for the economic and reputation motives. Contrary to our Hypothesis $4 b$, firms in Finland did not report higher CSR motives of social conformity and values compared with USA firms. We note that 
the overall pattern of importance attached to these motives by managers, ranked by mean response score, is identical for Finnish and US firms. For both, values motives ranked as the highest scoring item, with economic motives ranked lowest.

Table 3 Focus and level of socially responsible practices

\begin{tabular}{lcccc}
\hline & \multicolumn{3}{c}{ Liberal market context } & Coordinated market context \\
\cline { 2 - 5 } & Mean & $\begin{array}{c}\text { Standard } \\
\text { deviation }\end{array}$ & Mean & $\begin{array}{c}\text { Standard } \\
\text { deviation }\end{array}$ \\
\hline Focus & 2.49 & 1.26 & 2.24 & 1.32 \\
$\quad$ Arts and culture & 3.51 & 1.16 & 1.97 & 1.08 \\
$\quad$ Education & 2.41 & 1.30 & 1.75 & 1.03 \\
$\quad$ Environment & 3.26 & 1.37 & 2.53 & 1.30 \\
$\begin{array}{l}\text { Health and wellness } \\
\text { Social and public need }\end{array}$ & 3.94 & 1.03 & 1.89 & 1.04 \\
Level & 1.01 & 2.56 & 0.33 & 0.95 \\
$\quad \begin{array}{l}\text { Funds donated as a percentage } \\
\text { of annual revenue }\end{array}$ & 2.29 & 6.19 & 1.79 & 4.30 \\
$\quad \begin{array}{l}\text { Value of non-cash donations as } \\
\text { a percentage of annual revenue }\end{array}$ & 8.56 & 39.27 & 9.62 & 34.73 \\
$\begin{array}{l}\text { Average number of volunteer } \\
\text { days per employee }\end{array}$ & 0.38 & 0.67 & 3.42 & 12.88 \\
$\begin{array}{l}\text { Sponsorships as a percentage of } \\
\text { annual revenue }\end{array}$ & & & & \\
\hline
\end{tabular}

Table 4 Motives for and formalisation of social responsibility practices

\begin{tabular}{lcccc}
\hline & \multicolumn{3}{c}{ Liberal market context } & \multicolumn{2}{c}{ Coordinated market context } \\
\cline { 2 - 5 } & Mean & $\begin{array}{r}\text { Standard } \\
\text { deviation }\end{array}$ & Mean & $\begin{array}{c}\text { Standard } \\
\text { deviation }\end{array}$ \\
\hline Motive & & & & \\
Economic & 3.51 & 1.14 & 3.14 & 0.93 \\
Reputation & 4.97 & 1.43 & 4.26 & 1.31 \\
Social conformity & 4.51 & 1.37 & 4.07 & 1.55 \\
$\quad$ Values & 5.47 & 1.20 & 4.37 & 1.45 \\
Formalisation & 4.18 & 1.36 & 2.65 & 1.43 \\
\hline
\end{tabular}

In support of Hypothesis 5, firms in a liberal market economy report significantly higher formalisation of structures and processes for CSR within the firm ( $t$-value $=7.80$, $p<.01$ ). US respondents reported significantly greater use of all the CSR management methods than their Finnish counterparts. We interpret this to mean that in coordinated market economies, structures outside the firm (state or civic entities) provide significant support for organising and monitoring social needs, reducing the need for individual firms to allocate resources and design practices around CSR. For example, the item 'monitor important issues' indicated a particularly strong difference, with the US average 
response at 4.57 on the seven-point scale $(7=$ strongly agree) and the Finnish average at $2.76(t$-value $=7.01, p<.01)$. This finding supports the tenets of the explicit form of CSR where individual firms hold responsibility for issue monitoring. In addition, these results affirm the strategic, intentional nature of explicit CSR such that companies modify their internal practices to attain specific CSR outcomes.

\section{Discussion}

CSR encompasses a wide range of economic, legal and ethical responsibilities (Schwartz and Carroll, 2003). While the precise manifestation and direction of the responsibility lie at the discretion of the company (Matten and Moon, 2008), our research indicates that national institutional context has a significant impact on social practices as well as the motives that organisations have for engaging in socially responsible activities. Overall, our empirical findings support Matten and Moon's theory delineating explicit and implicit forms of CSR. While their argument emphasised how CSR is perceived, interpreted and displayed in different contexts, they suggest that perhaps CSR it is not truly different in terms of practice. Our research suggests differences in practices do exist because of the function that CSR serves within different societies. In liberal market economies, CSR is an overt signal of legitimacy and may serve as a proxy for firm quality and trustworthiness, yielding a significant reputational benefit precisely because CSR is voluntary and may serve to distinguish one firm from another. In coordinated market economies, CSR represents affirmation of societal values and participation in collective processes that are not intended to distinguish the organisation individually.

Our research provides a finer grained understanding of the role of CSR as a signalling device in liberal market contexts. Our data show that firms in the USA participated in CSR activities at greater rates but not necessarily at higher levels than Finnish firms suggesting that merely participating in certain forms of CSR may be a more important signal than the level of effort shown. For example, more US firms $(80 \%)$ participate in employee volunteering than Finnish firms (37\%), but on average Finnish firms donate more employee days than US firms. Similarly, more US firms provide sponsorships overall, but at significantly lower level than Finnish firms. However, more US firms give cash and non-cash donations, and they give larger proportions of their revenue than Finnish firms. An institutional explanation of this result is that the US institutional context encourages businesses to provide direct financial support to charitable organisations without government intervention in the relationship, in what EspingAndersen (1999) refers to as welfare capitalism. Institutional norms support cash and non-cash donations at widely agree upon levels in the USA, while providing volunteer days and sponsorships may be perceived as supplementary and more relevant for the firm's own benefit via employee development. In Finland, participation in volunteering and sponsorships is not expected, but firms that do participate exhibit high levels of engagement, suggesting substantive outcomes are more important than symbolic ones.

Our research also illuminated a little researched, but powerfully important element of CSR: the degree of formalisation of internal organisational structure and processes. We sought to identify the degree to which firms engaged in strategic and planned approaches 
to their CSR activities, integrated with their broader business goals (Porter and Kramer, 2006). Our findings of such an approach within US firms are consistent with Matten and Moon's (2008) interpretation of explicit CSR. Our measure of a firm's strategic orientation to CSR considers the degree to which firms link their practices with their business goals and establish goals for their CSR activities through formal reporting, formally engaging the community, obtaining senior management and employee commitment, and establishing plans to communicate their social practices to the wider community. Our finding that firms in liberal market economies have higher degrees of formalisation supports the argument that companies modify their internal practices to attain specific CSR outcomes and achieve individual distinction in explicit CSR contexts.

Additionally, this study provides new insights into the motives underlying CSR practices. Our findings suggest that motives for CSR fall into the four categories values, reputation, social conformity and economic - rather than the three categories economic, ethical and legal - that are typically identified in CSR research (Carroll, 1979; Schwartz and Carroll, 2003). The category of values was cited as the dominant motive for CSR in both the Finnish and US firms, and reputation was ranked second, capturing a relational dimension between a company and its community that is not represented in the Schwartz and Carroll (2003) model. Our re-conceptualisation of motives for CSR reveals that managers are concerned with legitimacy seeking behaviour that is not primarily linked to ethical or legal motives, suggesting the importance of the cognitive institutional dimension over mimetic or coercive forces (DiMaggio and Powell, 1983). Managers attend to the implied contract between society and the firm (Donaldson, 2008), making managerial judgements about CSR based on cognitive understanding and beliefs that are themselves influenced by the regulatory and normative dimensions of the institutional environment (Kostova and Roth, 2002; Scott, 2008). Drawing on our prior discussion and the results of our study, in Table 5 we summarise briefly how these three dimensions of firm-society relationships affect firms' CSR dispositions: regulatory institutions shaping the context for CSR; the norms associated with CSR in each country; and cognitive frames through which managers understand CSR reflecting the shared knowledge in society. Our findings indicate that future research on CSR should address all three institutional pillars but emphasise a greater understanding of managers' taken-for-granted scripts and how symbols, words or actions in the broader institutional context are interpreted (Scott, 2008).

Further research implications of our work include the importance of carefully defining constructs and measures in empirical CSR research addressing multiple institutional contexts. For example, our inductively derived measures support Matten and Moon's (2008) theory of implicit and explicit CSR, while Gjølberg's (2009) study of multinational firms in the OECD nations found Nordic countries had higher than average corporate performance in global CSR rankings than USA companies, contrary to the theory of explicit CSR. One reason for the difference may be that Gjølberg's (2009) study excluded key explicit CSR measures such as philanthropic giving (Brammer and Pavelin, 2005). Thus, research framed by the explicit form of CSR may fail to capture the full range of CSR present in contexts where the implicit form of CSR is dominant, and vice versa. 


\begin{tabular}{|c|c|c|}
\hline Institutional pillar & Liberal market economies (explicit CSR) & Coordinated market economies (implicit CSR) \\
\hline \multicolumn{3}{|l|}{ Regulatory } \\
\hline Social welfare provision & $\begin{array}{l}\text { - Welfare capitalism; private, market solutions } \\
\text { - Firms elect to participate in welfare provision (pensions, health, etc.) } \\
\text { - Greater emphasis on individual responsibility } \\
\text { organisatiofns on need-based approach }\end{array}$ & $\begin{array}{l}\text { - Universal welfare } \\
\text { - Public, non-market solutions, no or minor role for private } \\
\text { market provision } \\
\text { - Collective responsibility } \\
\text { - Firms mandated to participate in welfare provision } \\
\text { (pensions, health, etc.) }\end{array}$ \\
\hline Labour market policies & - Minimal & $\begin{array}{l}\text { - Extensive, legislated and enforced } \\
\text { - Co-determination; 'lifetime' perspective }\end{array}$ \\
\hline Corporate governance & $\begin{array}{l}\text { - Shareholder model. Search for short-term profit creates instrumental and } \\
\text { explicit communication of CSR; firms may be more exposed or susceptible } \\
\text { to external stakeholder activism }\end{array}$ & $\begin{array}{l}\text { - Cross-shareholdings between companies, financial } \\
\text { institutions and investors } \\
\text { - Seeking long-term sustainable relationship; CSR part of } \\
\text { business risk calculus }\end{array}$ \\
\hline $\begin{array}{l}\text { Business-government } \\
\text { relational modes }\end{array}$ & $\begin{array}{l}\text { - Adversarial; separation of firms from the state; preservation of autonomy } \\
\text { - } \text { Fragmented disassociated political//economic power } \\
\text { - Regulatory action contested political and legal process } \\
\text { Regulatory voids filed by consumer/stakeholder watchdogs }\end{array}$ & $\begin{array}{l}\text { Cooperative; high level of interest aggregation in concerted } \\
\text { policy development; firm engages in continuous process of } \\
\text { formal and informal bargaining with the state and business } \\
\text { groups } \\
\text { - Firm is embedded in a complex set of relationships, rights } \\
\text { and duties with the state } \\
\text { - State provides 'a shadow of strict regulation' }\end{array}$ \\
\hline \multicolumn{3}{|r|}{ C. } \\
\hline Conformity, duty & $\begin{array}{ll}\text { - Firms contribute market solutions to social needs as 'good citizens' } \\
\text { - Stronger populist undertones (e.g. USA) create shared expectation of } \\
\text { positive moral and ethical contribution by firms - on a voluntary basis }\end{array}$ & $\begin{array}{l}\text { - Firms are already 'good citizens' contributing to state-based } \\
\text { solutions via taxes, etc. } \\
\text { - Firms engaged in continuous dialogue with stakeholders via } \\
\text { legal frameworks governing business activities } \\
\end{array}$ \\
\hline \multicolumn{3}{|l|}{ Cognitive } \\
\hline $\begin{array}{l}\text { Managerial understanding } \\
\text { linking values and rationale }\end{array}$ & $\begin{array}{l}\text { - Managerial mindsets distinguish between economic and social role of firms } \\
\text { - Managerial discretion; rationalised processes } \\
\text { - Involvement in specific CSR practices according to business sector } \\
\text { - } \quad \text { Commitimacy seeking behaviour; reputational benefit } \\
\end{array}$ & $\begin{array}{ll}\text { - License to operate in local communities distinguished from } \\
\text { legislative requirements in search of long-term sustainability } \\
\text { - Driven internally by employee and managerial values tied to } \\
\text { production demands } \\
\text { - Less overt consideration of motives; more taken-for-granted } \\
\end{array}$ \\
\hline
\end{tabular}


Our conclusion that taken-for-granted beliefs do vary across national institutional context has practical implications for firms operating across countries with significant institutional expectations regarding CSR. Borrowing from Bartlett and Ghoshal's (1989) model of local responsiveness and global integration, a firm facing substantial differences in the context for CSR in a host versus home country will face pressures for local responsiveness. However, if that firm exercises explicit CSR, with a strong strategic orientation towards its social practices, it will seek to integrate as much of its global practice and policy as possible to provide coherence to its stakeholders. This is especially important for communicating consistency in its policies and practices to external groups, such as customers and NGOs. Recent work examining the CSR practices of MNEs operating in Mexico reveals firms adopting responsive product-market strategies will also pay greater attention to salient local CSR issues, such as employment creation (Husted and Allen, 2006). Further development and testing of our four dimensions values, reputational expectations, conformity and economic benefit - could provide a basis on which to develop country's institutional profiles for a CSR context providing a mechanism for measuring this form of institutional distance.

Our investigation of managerial understanding of the motives for CSR provides a useful first step in shifting to a more internationally grounded perspective of why firms engage in CSR. Given the limitations of our relatively small sample size and focus on only two countries to represent different national institutional contexts, further research should apply our constructs across a wider range of countries to confirm that these four dimensions are universally valid. This is especially so for emerging and developing markets. Our findings suggest that theories that assume a Western worldview are not only inadequate for addressing CSR in non-Western business contexts, but also fail to recognise the distinctions that exist between different varieties of contexts within Western nations. Matten and Moon (2008) suggest that the explicit model of CSR is spreading and becoming institutionalised around the world. Better tools for recognising, interpreting and articulating the implicit form of CSR are needed to avoid creating explicit CSR hegemony both in scholarship and in practice.

\section{References}

Aaronson, S.A. and Reeves, J. (2002) The European Response to Public Demands for Global Corporate Responsibility, National Policy Association, Washington, DC.

Bartlett, C.A, and Ghoshal, S. (1989) Managing Across Borders: The Transnational Solution, Harvard Business School Press, Boston, MA.

Baughn, C.C., Bodie, N.L. and McIntosh, J.C. (2007) 'Corporate social and environmental responsibility in Asian countries and other geographical regions', Corporate Social Responsibility and Environmental Management, Vol, 14, No. 4, pp.189-205.

Bertelsmann Stiftung Institute (2007) CSR navigator: public policies in Africa, the Americas, Asia and Europe. Available online at: http://www.bertelsmann-stiftung.de/bst/en/media/xcms_bst_ dms_22981_22982_2.pdf (accessed on 10 June 2008).

Brammer, S. and Pavelin, S. (2005) 'Corporate community contributions in the United Kingdom and the United States', Journal of Business Ethics, Vol. 56, No. 1, pp.15-26.

Brickson, S.L. (2007) 'Organizational identity orientation: the genesis of the role of the firm and distinct forms of social value', Academy of Management Review, Vol. 32, No. 3, pp.864-888.

Carroll, A. (1979) 'A three-dimensional conceptual model of corporate performance', Academy of Management Review, Vol. 4, No. 4, pp.39-48. 
Carroll, A.B. (1991) 'The pyramid of corporate social responsibility: toward the moral management of organizational stakeholders', Business Horizons, Vol. 34, No. 4, pp.39-48

Chapple, W. and Moon, J. (2005) 'Corporate social responsibility (CSR) in Asia: a seven-country study of CSR web site reporting', Business and Society, Vol. 44, No. 4, pp.415-441.

Crouch, C. and Streeck, W. (Eds) (1997) Political Economy of Modern Capitalism: Mapping Convergence and Diversity, Sage, Thousand Oaks, CA.

Davis, K. (1973) 'The case for and against business assumption of social responsibilities', Academy of Management Journal, Vol. 16, pp.312-323.

de Graaf, F.J. and Herkströter, C.A.J. (2007) 'How corporate social performance is institutionalised within the governance structure', Journal of Business Ethics, Vol. 74, No. 2, pp. 177-189.

Diamantopoulos, A., Reynolds, N.L. and Simintiras, A.C. (2006) 'The impact of response styles on the stability of cross-national comparisons', Journal of Business Research, Vol. 59, No. 8, pp.925-935.

DiMaggio, P.J. and Powell, W.W. (1983) 'The iron cage revisited: Institutional isomorphism and collective rationality in organizational fields', American Sociological Review, Vol. 48, pp. $147-160$.

Donaldson, T. (2008) 'The transatlantic paradox: how outdated concepts confuse the American/European debate about corporate governance', in Crane, A., McWilliams, A. Matten, D., Moon, J. and Siegel, D.S. (Eds): The Oxford Handbook of Corporate Social Responsibility, Oxford University Press, Oxford, pp.543-551.

Douglas, S.P. and Craig, C.S. (2007) 'Collaborative and iterative translation: an alternative approach to back translation', Journal of International Marketing, Vol. 15, No. 1, pp.30-43.

Esping-Andersen, G. (1999) Social Foundation of Postindustrial Economies, Oxford University Press, Oxford.

Eurobarometer (2008) Eurobarometer 69: public opinion in European Union. Available online at: http://www.ec.europa.eu/public_opinion/standard_en.htm (accessed on 10 June, 2008)

Eurofound (2006) Second European quality of life survey: overview. Available online at: http://www.eurofound europa.eu/pubdocs/2009/02/en/2/EF0902EN.pdf (accessed on 1 September 2009).

European Commission (2001) Promoting a European Framework for Corporate Social Responsibility, Green Paper (COM (2001)366). Available online at: http://ec.europa.eu/ enterprise/csr/policy.htm (accessed on 1 August 2009)

European Commission (2007) Corporate Social Responsibility: National Public Policies in the European Union. Available online at: http://ec.europa.eu/employment_social/soc-dial/csr/cst compendium_csr_en.pdf (accessed on 10 June 2008).

Fassin, Y. (2008) 'SMEs and the fallacy of formalizing CSR', Business Ethics: A European Review, Vol. 17, No. 4, pp.364-378.

Freeman, E.R. (1984) Strategic Management: A Stakeholder Approach, Pitmang, Boston, MA.

GAO (2005) Report to Congressional Requesters: Globalization - Numerous Federal Activities Complement US Business's Global Corporate Social Responsibility Effort, GAO-05-744. Available online at: http://www.gao.gov/new.items/d05744.pdf (accessed on 11 September 2008).

Gjolberg, M. (2009) 'Measuring the immeasurable? Constructing an index of CSR practices and CSR performance in 20 countries', Scandinavian Journal of Management, Vol. 25, No. 1 , pp. 10-22.

Goodrick, E. and Salancik, G. (1996) 'Organizational discretion in responding to institutional practices: hospitals and Cesarean births, Administrative Science Quarterly, Vol. 41, pp.1-28.

Guthrie, D. (2003) Survey on Corporate-Community Relations, Social Sciences Research Council, New York.

Habisch, A., Jonker, J., Wegner, M. and Schmidpeter, R. (Eds) (2005) Corporate Social Responsibility Across Europe, Springer, Berlin. 
Hall, P.A. and Gingerich, D.W. (2004) Varieties of capitalism and Institutional Complementarities in the Macroeconomy: An Empirical Analysis, Discussion Paper 04/5, Max Planck Institute for the Study of Societies, Cologne, Germany. Available online at: http://www.mpi-fgkoeln.mpg.de/pu/dp03-05_en.html (accessed on 23 March 2005)

Hall, P.A. and Soskice, D. (2001) 'Introduction,' in Hall, P.A. and Soskice, D. (Eds): Varieties of Capitalism: The Institutional Foundations of Comparative Advantage, Oxford University Press, New York, pp.1-69.

Hofstede, G. (2001) Culture's Consequences: Comparing Values, Behaviors, Institutions and Organizations across Nations, 2nd ed., Sage, Thousand Oaks, CA.

Hollingsworth, J.R. and Boyer, R. (Eds) (1997) 'Coordination of economic actors and social systems of production', in Hollingsworth, J.R. and Boyer, R. (Eds): Contemporary Capitalism: The Embeddedness of Institutions, Cambridge University Press, Cambridge, pp. $1-48$.

Husted, B.W. and Allen, D.B. (2006) 'Corporate social responsibility in the multinational enterprise: strategic and institutional approaches', Journal of International Business Studies, Vol. 37, No.6, pp.838-849.

Jamali, D., Zanhour, M. and Keshishian, T. (2009) 'Peculiar strengths and relational attributes of SMEs in the context of CSR', Journal of Business Ethics, Vol. 87, No. 3, pp.355-377.

Jepperson, R.L. (2002) 'Political modernities: disentangling two underlying dimensions of institutional differentiation', Sociological Theory, Vol. 20, No. 1, pp.61-85.

Katzenstein, P.J. (1985) Small States in World Markets: Industrial policy in Europe, Cornell University Press, Ithaca.

Kitschelt, H., Lange, P., Marks, G. and Stephens, J.D. (1999) 'Convergence and divergence in advanced capitalist democracies', in Kitschelt, H., Lange, P., Marks, G, and Stephens, J.D. (Eds): Continuity and Change in Contemporary Capitalism, Cambridge University Press, Cambridge, pp. $427-460$.

Korhonen, J. and Seppala, N. (2005) 'The strength of a high-trust society', in Habisch, A., Jonker, J., Wegner, M. and Schmidpeter, R. (Eds): Corporate Social Responsibility Across Europe, Springer, Berlin, pp. 15-22.

Kostova, T. and Roth, K. (2002) 'Adoption of an organizational practice by subsidiaries of multinational corporations: institutional and relational effects', Academy of Management Journal, Vol. 45, No.1, pp.215-233.

Kotler, P. and Lee, N. (2005) Corporate Social Responsibility: Doing the Most Good for Your Company and Your Cause, John Wiley \& Sons, Hoboken, NJ.

Lee, L. and Higgins, C. (2001) 'Corporate volunteering: ad hoc interaction or route of dialogue and partnership', Journal of Corporate Citizenship, Vol. 4, pp.79-90.

Mack, R.W. (1999) 'Event sponsorship: an exploratory study of small business objectives, practices, and perceptions', Journal of Small Business Management, Vol. 37, No. 3, pp.25-30.

Maignan, I. and Ralston, D.A. (2002) 'Corporate social responsibility in Europe and the US insights from businesses' self-presentations', Journal of International Business Studies, Vol. 33, No. 3, pp.497-514.

Marquis, C., Glynn, M.A. and Davis, G.F. (2007) 'Community isomorphism and corporate social action', Academy of Management Review, Vol. 32, No. 3, pp.925-945.

Matten, D. and Moon, J. (2008) "IImplicit" and "explicit" CSR: a conceptual framework for a comparative understanding of corporate social responsibility', Academy of Management Review, Vol. 33, No. 2, pp.404-424.

Meyer, J. and Rowan, B. (1977) 'Institutionalized organizations: formal structure as myth and ceremony', American Journal of Sociology, Vol. 83, pp.340-363.

Murillo, D. and Lozano, J. (2006) 'SMEs and CSR: an approach to CSR in their own words', Journal of Business Ethics, Vol. 67, No. 3, pp.227-240.

Nettl, J.P. (1968) 'The state as a conceptual variable', World Politics, Vol. 20, pp.559-592. 
OECD (2008) Country statistical profiles 2008. Available online at: http://stats.oecd.org/ WBOS/Index. aspx? DatasetCode $=$ CSP2008 (accessed on 26 September 2008).

Orlitzky, M., Schmidt, F.L. and Rynes, S. (2003) 'Corporate social and financial performance: a meta-analysis', Organization Science, Vol. 24, pp.403-441.

Panapanaan, V.M., Linnanen, L., Karvonen, M. and Vinh, P.T. (2003) 'Roadmapping corporate social responsibility in Finnish companies', Journal of Business Ethics, Vol. 44, Nos. 2-3, pp.133-148.

Perrini, F., Russo, A. and Tencati, A. (2007) 'CSR strategies of SMEs and large firms: evidence from Italy', Journal of Business Ethics, Vol. 74, pp.285-300.

Porter, M.E. and Kramer, M.R. (2006) 'Strategy and society: the link between competitive advantage and corporate social responsibility', Harvard Business Review, Vol. 84, No. 12 , pp. 78-92.

Russo, A and Tencati, A. (2009) 'Formal vs. informal CSR strategies: evidence from Italian micro, small, medium-sized, and large firms', Journal of Business Ethics, Vol. 85, Suppl. 2, pp.339-353.

Saiia, D.H., Carroll, A.B. and Buchholtz, A.K. (2003) 'Philanthropy as strategy: when corporate charity "begins at home"”, Business and Society, Vol. 42, No. 2, pp.169-201.

Schmitter, P.C. (1974) 'Still the century of corporatism?', Review of Politics, Vol. 36, pp.85-131.

Schwartz, M.S. and Carroll, A.B. (2003) 'Corporate social responsibility: a three-domain approach', Business Ethics Quarterly, Vol. 13, No. 4, pp.503-530.

Scott, W.R. (2008) Institutions and organizations, Sage, Thousand Oaks, CA.

Scruggs, L.A. (1999) 'Institutions and environmental performance in seventeen western democracies', British Journal of Political Science, Vol. 29, No. 1, pp.1-31.

Seifert, B., Morris, S.A. and Bartkus, B.R. (2004) 'Having, giving and getting: slack resources, corporate philanthropy and firm financial performance', Business and Society, Vol. 43, No. 2, pp. 135-161.

Spence, L. (2007) 'CSR and small business in a European policy context: the five "C"s of CSR and small business research agenda 2007', Business and Society Review, Vol. 112, No. 4, pp.533-552.

Spencer, J.W., Murtha, T.P. and Lenway, S.A. (2005) 'How governments matter to new industry creation', Academy of Management Review, Vol. 30, pp.321-337.

Statistics Finland (2008) Finnish enterprises. Available online at: http://www.stat.fi/index_en.html (accessed on 9 May, 2008).

The Observatory of European SMEs (2002) European SMEs and Social and Environmental Responsibility, Report No. 4. Available online at: http://ec.europa.eu/enterprise/enterprise policy/analysis/doc/smes_observatory_2002_report4_en.pdf (accessed on 15 September 2008).

Thomas, L.G. and Waring, G. (1999) 'Competing capitalisms: capital investment in American, German, and Japanese firms', Strategic Management Journal, Vol. 20, No. 8, pp.729-748.

Thompson, J.K., Smith, H.L. and Hood, J.N. (1993) 'Charitable contributions by small businesses', Journal of Small Business Management, Vol. 31, No. 3, pp.35-51.

US Census Bureau (2008) State \& county quickfacts. Available online at: http:/quickfacts.census.gov/qfd/states/53/53053.html (accessed on 10 September 2008).

US Census Bureau (2009) US census bureau, current population survey, annual social and economic supplements. Available online at: http://www.census.gov/hhes/www/income/histinc/ h04.xls (accessed on 1 September 2009).

Useem, M. (1988) 'Market and institutional factors in corporate contributions', California Management Review, Vol. 30, No. 2, pp.77-88.

Useem, M. (1991) 'Organizational and managerial factors in the shaping of corporate social and political action', Research in Corporate Social Performance and Policy, Vol. 12, pp.63-92. 
Vives, A. (2006) 'Social and environmental responsibility in small and medium enterprises in Latin America', Journal of Corporate Citizenship, Vol. 21, pp.39-50.

Vogel, D. (1996) 'The study of business and politics', California Management Review, Vol. 38, No. 3, pp.146-165.

Vuontisjärvi, T. (2006) 'Corporate social reporting in the European context and human resource disclosures: an analysis of Finnish companies', Journal of Business Ethics, Vol. 69, No. 4, pp.331-354.

Welford, R. (2005) 'Corporate social responsibility in Europe, North America and Asia', Journal of Corporate Citizenship, Vol. 17, pp.33-52.

Whitley, R. (1999) Divergent Capitalisms: The Social Structuring and Change of Business Systems, Oxford University Press, New York.

Williams, C.A. and Aguilera, R.V. (2008) 'Corporate social responsibility in a comparative perspective', in Crane, A., MoWilliams, A., Matten, D., Moon, J. and Siegel, D.S. (Eds): The Oxford Handbook of Corporate Social Responsibility, Oxford University Press, Oxford, pp. $452-472$.

World Values Survey (2000) Survey data files. Available online at: http://www.worldvaluessurvey.org (accessed on 10 September 2008). 


\section{Appendix A: Study measures}

Motives for socially responsible practices

Economic $\left[\alpha_{\text {sample }}=.89 ; \alpha_{\text {liberal }}=.86 ; \alpha_{\text {coordinated }}=.91\right]$

Sets us apart from competitors

Positive impact on company's financial value

Positive impact on profits

Benefits our customers directly

Increases customer loyalty

Supports business goals

Have resources available to give

Reputation $\left[\alpha_{\text {sample }}=.79 ; \alpha_{\text {iberal }}=.82 ; \alpha_{\text {coordinated }}=.73\right]$

Personal relationships in the community

Our company's standing in the community

How we appear to others in the business community

Improves our image and reputation

Social conformity $\left[\alpha_{\text {sample }}=.74 ; \alpha_{\text {liberal }}=.79 ; \alpha_{\text {coordinated }}=.68\right]$

Important issues in the community

Local political considerations

Local government programmes and incentives

Local laws and policies

Historical patterns of giving in the community

Expectations of the community

What other companies are doing

Values $\left[\alpha_{\text {sample }}=.72 ; \alpha_{\text {liberal }}=.59 ; \alpha_{\text {coordinated }}=.74\right]$

Reflects company values and culture

Reflects the values of people who work here

Helps attract and retain employees

Formalisation of socially responsible practices $\left(\alpha_{\text {sample }}=.91 ; \alpha_{\text {liberal }}=.85 ; \alpha_{\text {coordinated }}=.92\right)$

Form employee teams to develop plans

Include community partners in plan development

Establish goals for the company's social practices

Develop a communications plan for social practices

Link social practices with business strategy

Get senior management buy-in

Measure and report outcomes

Monitor status of issues that initiatives are supporting 